Revue des patrimoines

$25 \mid 2014$

Le patrimoine de la Grande Guerre

\title{
Première Guerre mondiale et monuments historiques
}

Rapport de l'Inspection des patrimoines, Collège des Monuments historiques, Direction générale des patrimoines, novembre 2012

Marc Botlan, Colette di Matteo, Caroline Piel, Olivier Poisson and MarieAnne Sire

\section{(2) OpenEdition}

Journals

Electronic version

URL: http://journals.openedition.org/insitu/11605

DOI: 10.4000/insitu. 11605

ISSN: 1630-7305

Publisher

Ministère de la Culture

\section{Electronic reference}

Marc Botlan, Colette di Matteo, Caroline Piel, Olivier Poisson and Marie-Anne Sire, « Première Guerre mondiale et monuments historiques », In Situ [Online], 25 | 2014, Online since 18 December 2014, connection on 26 June 2020. URL : http://journals.openedition.org/insitu/11605 ; DOI : https:// doi.org/10.4000/insitu.11605

This text was automatically generated on 26 June 2020 .

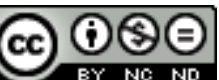

In Situ Revues des patrimoines est mis à disposition selon les termes de la licence Creative Commons Attribution - Pas d'Utilisation Commerciale - Pas de Modification 4.0 International. 


\title{
Première Guerre mondiale et monuments historiques
}

\author{
Rapport de l'Inspection des patrimoines, Collège des Monuments
}

historiques, Direction générale des patrimoines, novembre 2012

Marc Botlan, Colette di Matteo, Caroline Piel, Olivier Poisson and MarieAnne Sire

$1 \quad$ Voir le rapport en annexe.

\section{ABSTRACTS}

The First World War and its protected monuments. Some time before the year 2014 and its planned commemoration of the Great War, the heritage directorate within the French ministry of culture asked a group of its historic monuments inspectors to prepare a report on the state of the protection of the vestiges of the war under the terms of the law on historic monuments. The present text, drawn up in November 2012, gives the contents of the report, providing a survey of all the historic monuments in France and its overseas departments relating to the First World War. These monuments include a handful of battlefield vestiges, preserved as monuments in ruin shortly after the conflict, war memorials erected during the inter-war period and military necropolises and cemeteries. The report concludes with some methodological recommendations for future measures of protection.

À l'approche de l'année 2014 et de sa commémoration programmée de la Première Guerre mondiale, la Direction générale des patrimoines au sein du Ministère de la Culture et de la Communication, a demandé au collège des monuments historiques de l'Inspection des patrimoines de réfléchir à la question des protections des vestiges et témoignages du conflit. Rédigé en novembre 2012, ce présent texte est le rapport présenté à la Direction générale des 
patrimoines, faisant un bilan, à cette date, de la protection au titre des monuments historiques du patrimoine lié à la Première Guerre mondiale, englobant les ruines protégées au lendemain du conflit, les monuments aux morts érigés entre les deux guerres, et les mémoriaux, cimetières et nécropoles militaires. Le rapport se termine par quelques recommandations méthodologiques pour l'examen de futures demandes de protection.

INDEX

Mots-clés: Première Guerre mondiale, monuments historiques, ruines de guerre, monuments aux morts, mémoriaux, nécropoles militaires

Keywords: World War One, historic monuments, scheduled monuments, listed monuments, war ruins, war memorials, military cemeteries, necropolis

\section{AUTHORS}

\section{CAROLINE PIEL}

caroline.piel@culture.gouv.fr

OLIVIER POISSON

olivier.poisson@culture.gouv.fr

MARIE-ANNE SIRE

marie-anne.sire@culture.gouv.fr 